\title{
A multi-site assessment of knowledge of Ebola virus disease among health workers in south-west Nigeria
}

\author{
*Joseph A.O. ${ }^{1}$, Mohammed A.Y. ${ }^{1}$, Raji A. ${ }^{1}$, Atolagbe E. ${ }^{1}$, Joseph A. ${ }^{2}$, Kadiri K. ${ }^{3}$
}

\begin{abstract}
Objective: Nigeria may have been certified free from Ebola Virus Disease (EVD) by the World Health Organization, but not without its aftermath on many, especially among health workers who came in contact with the infected during the West African outbreak in 2014.This study was conducted among health workers in three tertiary hospitals in South-West Nigeria. It aimed at assessing their knowledge of EVD in a bid to forestall future contagion from patients.
\end{abstract}

Method: 600 consenting participants selected through two-stage sampling method were involved in the study. Primary data was retrieved through self-administered questionnaire.

Results: Majority (84.0\%) of the participants knew that EVD can be contacted through blood and bodily fluid of an infected person, (78.0\%) knew that EVD can be prevented by avoiding contact with an infected person, while (76.0\%) identified bleeding from orifices as one of the signs of EVD. However, $(6.0 \%)$ of the participants did not know how EVD can be prevented.

Conclusion: Result showed that participants have average knowledge of EVD and therefore, are not adequately informed of EVD. The study recommended wider dissemination of adequate information on EVD among health workers in tertiary hospitals to forestall future contagion of the infection from patients.

Keywords: Knowledge, EVD, Contagion, Outbreak, Prevention, Bleeding

*Corresponding Author: Joseph A.O.; E-mail: Josepholuyemi1@gmail.com

'Department of Sociology, University of Ilorin, Ilorin. Nigeria

${ }^{2}$ Department of Medical Microbiology and Parasitology, Bowen University, Iwo, Osun State.

${ }^{3}$ Department of Mass Communication, University of Ilorin, Ilorin, Nigeria.

Research Journal of Health Sciences subscribed to terms and conditions of Open Access publication. Articles are distributed under the terms of Creative Commons Licence (CC BY-NC-ND 4.0). (http://creativecommons.org/licences/by-nc-nd/4.0).

http://dx.doi.org/10.4314/rejhs.v5i3.5 


\title{
Une évaluation multi-sites de la connaissance de la maladie à virus Ebola chez les travailleurs de la santé dans le sud-ouest du Nigeria
}

\begin{abstract}
Resume
Objective: Le Nigéria a été certifié indemne de maladie à virus Ebola (MVE) par l'Organisation mondiale de la santé, mais pas sans conséquences pour de nombreuses personnes, en particulier les agents de santé qui ont été contaminés par l'épidémie en Afrique de l'Ouest en 2014. Cette étude Il a été mené auprès de professionnels de la santé dans trois hôpitaux tertiaires du Sud-Ouest du Nigeria, dans le but d'évaluer leur connaissance de la MVE dans le but de prévenir la contagion future des patients.

Méthode: Six cents participants consentants sélectionnés au moyen d'une méthode d'échantillonnage en deux étapes ont participé à l'étude. Les données primaires ont été récupérées grâce à un questionnaire autoadministré.
\end{abstract}

Resultants: La majorité (84,0\%) des participants savaient que la MVE pouvait être contactée par le sang et les fluides corporels d'une personne infectée $(78,0 \%)$ savait que la MVE pouvait être évitée en évitant le contact avec une personne infectée, tandis que $(76,0 \%)$ saignement des orifices comme l'un des signes de la maladie à virus Ebola. Cependant, $(6,0 \%)$ des participants ne savaient pas comment prévenir la MVE.

Conclusion: Au total, les résultats ont montré que les participants ont une connaissance moyenne de la MVE. L'étude a recommandé une diffusion plus large d'informations adéquates sur la MVE parmi les agents de santé dans les hôpitaux tertiaires afin de prévenir la contagion future de l'infection par les patients.

Mots-clés: Connaissance, MVE, Contagion, Epidémie, Prévention, Saignement

*Auteur correspondant: Joseph A.O.; E-mail: Josepholuyemi1@gmail.com

'Department of Sociology, University of Ilorin, Ilorin. Nigeria

${ }^{2}$ Department of Medical Microbiology and Parasitology, Bowen University, Iwo, Osun State.

${ }^{3}$ Department of Mass Communication, University of Ilorin, Ilorin, Nigeria.

Research Journal of Health Sciences subscribed to terms and conditions of Open Access publication. Articles are distributed under the terms of Creative Commons Licence (CC BY-NC-ND 4.0). (http://creativecommons.org/licences/by-nc-nd/4.0).

http://dx.doi.org/10.4314/rejhs.v5i3.5 


\section{INTRODUCTION}

Ebola virus disease also known as Ebola haemorrhagic fever (EHF) was first discovered in West Africa in 1976 (1). It is a viral haemorrhagic fever of human and other primates caused by the Ebola virus which is very virulent; killing, between 25 and 90 per cent of those infected with an average death of 50 per cent (2). This it does by lowering of blood pressure from blood/body fluid which typically occurs six to sixteen days after symptoms of the disease have appeared (3).

Symptoms usually start between two days and three weeks after a person contracts the virus with fever, sore throat, muscular pain, and headaches which later progress to vomiting, diarrhoea and rash alongside decreased function of the liver and kidneys and may eventually lead to internal and external bleeding (1). Although the outbreak of the disease have occurred intermittently in tropical region of sub-Saharan Africa between 1976 and 2003, the largest outbreak was the one recorded in the region in 2014 involving Guinea, Sierra Leone and Nigeria in which 28,512 cases was reported resulting in 11,313 deaths $(2,4,5)$.

However, since the first reported outbreak in 1976, infections acquired in health care facilities have been recognised as an important cause of morbidity and mortality particularly among health workers (5). Doctors and other health workers in the front lines of combatting the Ebola outbreak have been among the most vulnerable to the infection as they are in direct physical contact with patients. The first case of the deadly EVD in Nigeria was a Liberian-American who flew from Liberia to Nigeria's most populated city of Lagos in July 2014 (6). Within few weeks from this index case, 20 cases and 8 deaths had occurred as a result of the disease; four of which were health workers $(1,2)$.

Two medical doctors, a Consultant Endocrinologist who attended to the index case and another doctor who attended to a patient that had contact with the index case were said to have dies shortly in an hospital in Lagos and in the Port-Harcourt respectively $(7,8)$. Despite the significance of information on such diseases, only very few studies that have been conducted on Ebola virus disease among health workers in Nigeria (9). Previous study conducted among health workers in a tertiary hospital in SouthWest Nigeria suggests that, over half of the health workers involved in the study have poor knowledge of EVD and would require attitudinal change to avert uncontrollable epidemic of the disease in the future (10).

It is against this backdrop that, this study investigates the knowledge of EVD among health workers in some teaching hospitals in Nigeria. The aim of the study is to know if health workers in these hospitals are adequately informed about the disease.

\section{Theoretical Perspective}

The study was explained with the Theory of Reasoned Action (TRA). The theory was proposed by Fishbein and Ajzen in 1967 (11). TRA explains the relationship between attitude and behaviour within the human action context. The theory focuses on individual's basic motivation to perform an action, that is, intention to perform certain behaviour. The theory contends that, an individual's decision to engage in a particular behaviour depends on the expected outcomes of which such behaviour is performed (12). It therefore proposed that, the stronger the intention an individual have towards an action, the stronger the likelihood for such behaviours to be performed.

Resting on this platform, we hypothesize that due to previous incidences of infection of EVD from patients and subsequent death of health workers from such infection, there will be stronger intention by health workers to seek adequate knowledge about EVD and how it can be prevented in order to avert future occurrence of infection from patients.

\section{MATERIALS AND METHODS}

The study was conducted in three tertiary hospitals in South-West Nigeria namely: Obafemi Awolowo University Teaching Hospital, Ile-Ife, Osun State. Ladoke Akintola University Teaching Hospital, Ogbomoso, Oyo State and University of Ilorin Teaching hospital, Ilorin, Kwara State. These hospitals were selected for the study because they fall in the 
South-Western region of the country where the index case of EVD was recorded. Six hundred (600) consenting participants cutting across a wide range of health workers in the three hospitals were involved in the study. The study employed a two staged sampling techniques involving first, purposive sampling of the three tertiary hospitals and thereafter, a simple random sampling of the participants in the sampled population.

Two hundred participants were selected from each hospital using the non-probability sampling method to represent health workers in each hospital. Primary data was retrieved through self-administered structured questionnaire that included both closed and open ended questions. Each questionnaire contained questions relating to the socio-demographic characteristics of the participants and questions relating to the knowledge of EVD. Data retrieved from the field was analysed with the Statistical Package for Social Science (SPSS version 19.0) and were presented in tables using frequencies and simple percentages. A p-value of $<0.05$ is said to be statistically significant. Three research assistants helped in distributing the questionnaires to the participants and explained the contents to them for clarity. Informed consent was also obtained from the participant before carrying out the research.

\section{RESULTS}

Six hundred and fourty-seven (647) questionnaires were distributed out of which 600 returned with response, giving a response rate of $92.7 \%$.

Social demographic factors in Table 1 revealed an almost evenly distributed sample size with $(57.3 \%)$ male representing and (42.7\%) female. Majority of the participants, which were within the 31-40 age group while $(50.5 \%)$ were Christians (83.0\%). The Yoruba tribe dominated, representing $(91.3 \%)$ of participants with the other tribes like Igbo, Ibira, Ijaw and Edo being constituting the minority $(8.7 \%)$. Participants were mainly nurses $(30.7 \%)$, followed closely by medical doctors $(21.2 \%)$, and pharmacists (15.3\%). Other health workers like Community Health Extension Workers (9.7\%), laboratory staff $(10.8 \%)$ and other members of staff working in the hospital like portals and health records staff $(12.3 \%)$ were also captured.

On knowledge of how EVD can be contacted as shown in Table 2, 76.0\% of the participants identified contact with blood and body fluids of an infected person as a means, $5.0 \%$ identified eating of Bush meat, (1.7\%) believes it's through the air, (1.7\%) thinks it's from leftover food, (1.3\%) thinks it is through sex, $1.0 \%$ identified hand shake while (2.7\%) had no idea how EVD can be contacted.

Table 3 depicts participants' knowledge on how the disease can be prevented. (78.0\%) of the participants identified prevention of direct contact with an infected person, (28.7\%), universal precaution, $(21.3 \%)$ prevention of rodents from contact with food items, (14.7\%) avoiding contact with animals, $(8.7 \%)$ identified the practice of proper hygiene, $(5.0 \%)$ Isolation of an infected person, $(2.3 \%)$ identified Surveillance and contact tracing while $(6.0 \%)$ mentioned that they have no idea of how EVD can be prevented.

In assessing the knowledge of participants on signs and symptoms of EVD as shown in table $4,(76.0 \%)$ participants stated bleeding from the Orifice as the symptom of EVD, (18.7\%) mentioned body pains as a symptom. Other symptoms, according to participants were Diarrhoea(24.0\%), fatigue $(8.7 \%)$, fever $(47.3 \%)$, head ache $(28.0 \%)$, skin rashes $(7.0 \%)$, red eyes( $5.0 \%)$, sore throat $(11.3 \%)$, stomach pain $(5.7 \%)$, vomiting $(17.0 \%)$, weakness of the body $(14.0 \%)$, high body temperature $(30.3 \%)$, Malaise $(3.0 \%)$ and multiple organ failure $(1.3 \%)$ while $(2.7 \%)$ do not know any sign and symptom of the disease.

Table 5 on the other hand showed the overall level of knowledge of participants, based on responses to questions on general knowledge about EVD, its means of transmission, prevention and signs and symptoms. Each response given scores a point and participants are said to have a good knowledge of the disease if participant has a score of $>10$ points, average knowledge with a score of 5-10 points and poor knowledge with a score of $<5$ points. (32.7\%) of participants were found to have good knowledge 
of EVD, (48.0\%) have average knowledge while $(19.3 \%)$ have poor knowledge of the disease. Majority of doctors were found to have good knowledge of the disease $(64.6 \%)$ while majority of the nurses $(56.5 \%)$, pharmacist $(45.7 \%)$, CHEW (56.9\%) and laboratory staff (55.4\%) have average knowledge. Other health workers generally have poor knowledge of the disease.

\section{DISCUSSION}

Result from the study showed that, participants have average knowledge of EVD as indicated in table 5. This result is however, not in agreement with previous study conducted in IleIfe, South-West Nigeria, among health workers where, more than half of the sampled population had poor knowledge of EVD (10). The result is also not in tandem with the findings of earlier studies conducted among health workers in a tertiary hospital in Osun State in south-western Nigeria that suggests good knowledge of EVD among participants $(13,14)$. On the knowledge of how EVD can be contacted, majority of the participants in the study identified contact through blood and bodily fluids of an infected person. This rests on previous research where the highest means of contacting EVD identified by participants was through the blood (15).

As regards participants knowledge of how EVD can be prevented, more than three quarter of the participants in the study identified avoiding direct contact with an infected person, this was followed closely by the practice of universal precaution such as the use of hand gloves, facial mask etc. when attending to patients. This finding also differs from previous study where the highest means of prevention of EVD identified by participants was environmental sanitation (15). However, on signs and symptoms of EVD, three quarter of the participants in the study identified bleeding from the orifice which was followed by fever and high body temperature. This result agrees with the finding of study conducted among health workers in Ondo State Southwest Nigeria where bleeding was the most identifies sign and symptom of EVD but differs from study conducted among health workers in Lagos state where the highest identified sign and symptom of EVD among participants was fever $(13,16)$.

\section{CONCLUSION}

The study has been able to assess the knowledge of EVD among health workers in three tertiary hospitals in South-West Nigeria. The hospitals included in the study are: Obafemi Awolowo University Teaching Hospital, Ile-Ife, Osun State. Ladoke Akintola University Teaching Hospital, Ogbomoso, Oyo State and University of Ilorin Teaching hospital, Ilorin, Kwara State. 600 participants drawn through a two-staged sampling method were involved in the study, in which 200 respondents were randomly selected in each hospital. Result from the study shows that, participants have average knowledge of EVD and therefore, are not adequately informed of EVD. The study therefore strongly recommends an improvement in the knowledge of health workers towards EVD to forestall future infection of the virus from patients.

Acknowledgement: The authors wish to thank the editors of Research Journal of Medical Research and the three reviewers for their helpful comments and suggestions. We are also grateful to our three research assistants for their patience and perseverance during the study as well as all our participants for their consent and contribution to the study.

Conflict of Interest: The authors declares no conflict of interest.

\section{References}

1. World Health Organization (September2014). Ebola Virus Disease Fact Sheet. No 103. A v a i 1 a b 1 e from : http://www.who.int/mediacentre/factsheets/fs10 3/en/.Accessed 02/10/16

2. World Health Organization (April 21 2014). Ebola Virus Disease outbreak in West Africa. A v a i 1 a b 1 e from : http://www.who.int/ith/updates/20140421/en/. Accessed 03/10/16.

3. Singh, D (2014). Viral hemorrhagic fevers. Boca Raton: CRC Press, Taylor \& Francis Group. p. 444.

4. Centre for Disease Control (August 4 2014). 
2014 Ebola Virus Outbreak in West Africa. A v a i l a b l e f r o m : https://www.cdc.gov/vhf/ebola/outbreaks/2014west-africa/. Accessed October 42016.

5. World Health Organization (May 21 2015). Health worker Ebola infections in Guinea, Liberia and Sierra Leone. Available from http://www.who.int/hrh/documents/21 may2015 _web_final.pdf.Accessed 04/10/16

6. Mark, M (2014). Ebola Outbreak: Nurse who Treated First Victim in Nigeria Dies. The Guardian. Accessed on 20 May 2016.

7. Ibeh, N. (2014). Ebola Outbreak in Nigeria. Premium Times. Available at: www.premiumtimesng.com/author/nnena$\mathrm{ibeh/page/17.} \mathrm{Accessed} \mathrm{on} \mathrm{19} \mathrm{May} 2016$.

8. Cocks, T., and Payne, J (2014). Doctor Dies of Ebola in Nigeria's Oil Hub Port- Harcourt. Reuters, Canada. Pp 2.Accessed on 15 March 2016.

9. Centre for Public Policy Alternatives. (2014). Study on the Ebola Virus Disease (EVD): Knowledge, Attitudes and Practices of Nigerians in Lagos State. Lagos, Nigeria: Centre for Public Policy Alternatives;. p. 3-12.

10. Yakubu, A., Folayan, M. O., Sani-Gwarzo, N., Nguku, P., Peterson, K., and Brown, B (2014). The Ebola outbreak in Western Africa: Ethical Obligations for care, Journal of Medical Ethics pp medethics.

11. Fishbein, M. and Ajzen, I. (1975). Belief, attitude, intention, and behaviour: An introduction to theory and research. Reading, MA: Addison-Wesley

12. Rogers G. M., Archibald, M., Morrison, D., Wilsdon, A., Wells, E., Hoppe, M., Nahom, D., Murowchick, E., (2002). "Teen Sexual Behaviour: Applicability of the Theory of Reasoned Action". Journal of Marriage and Family (Volume 64)

13. Oladimeji, A.M., Gidado. S., Nguku, P., Nwangwu, I.G., Patil, N.D., Oladosu, F., Roberts, A.A, Waziri,N.E., Shuaib, F., Oguntimehin, O.,Musa, E., Nasidi, A., Adewuyi, P.,Olayinka, A., Odubanjo, O., N-FELTP Residents and Poggensee, G (2015). Ebola virus disease - gaps in knowledge and practice among healthcare workers in Lagos. Tropical Medicine and International Health.20(9):1162-1170.
Accessed $16^{\text {th }}$ March 2017.

14. Adepimpe, W.O (2016). Knowledge, Attitude, and Practice of Use of Safety Precautions Among Health Care Workers in a Nigerian Tertiary Hospital, 1 Year After the Ebola Virus Disease Epidemic. Annals of Global Health. Volume 82, I s s u e 5. P p $897-902$. Availablefrom:http://www.sciencedirect.com/sc ience/article/pii/S22 14999616307536. Accessed 11June 2017.

15. Olowookere, S.A., Abioye-Kuteyi, E.A., Adepoju, O.K., Esan, O.T., Adeolu, T.M., Adeoye, T.K., Adepoju, A.A., and Aderogba, A.T (2015).Knowledge, Attitude and Practice of Health Workers in a Tertiary Hospital in Ile-Ife, Nigeria, Towards Ebola Virus Disease. Journal of Tropical Medicine.

16. Ilesanmi, O., and Alele, F.O(2016). Knowledge, Attitude and Perception of Ebola Virus Disease among Secondary School Students in Ondo State, Nigeria. 


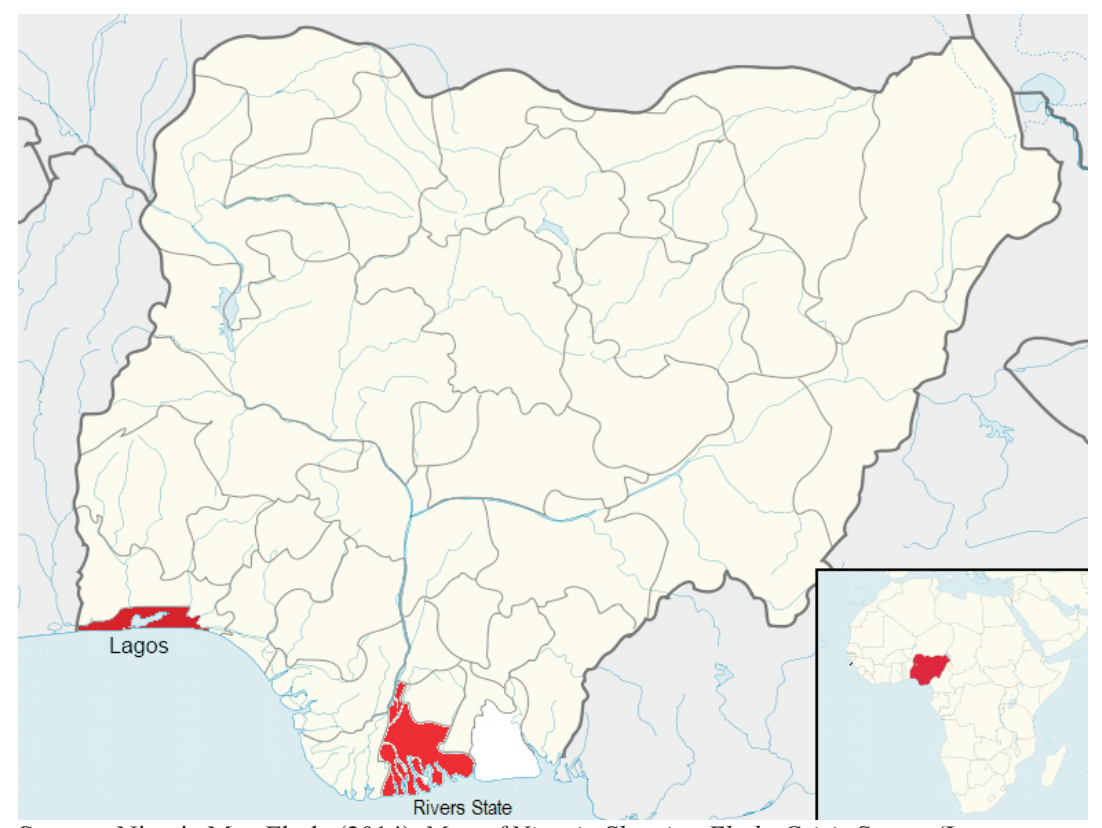

Source: Nigeria Map Ebola (2014). Map of Nigeria Showing Ebola Crisis States (Lagos and Port Harcourt ). Available at: http://commons.wikimedia.org/wiki/File:Blank_MapAfrica.svg

Figure 1: Map of Nigeria showing Locations with Ebola cases (Lagos and Port Harcourt)

Table 1: Socio-Demographic characteristics of Participants

\begin{tabular}{|c|c|c|}
\hline Socio-demographic & Frequency & Percentage (\%) \\
\hline \multicolumn{3}{|l|}{ Sex } \\
\hline Male & 256 & $(42.7)$ \\
\hline Female & 344 & (57.3) \\
\hline Total & 600 & $(100.0)$ \\
\hline \multicolumn{3}{|l|}{ Age group (years) } \\
\hline$=30$ & 231 & $(38.5)$ \\
\hline $31-40$ & 303 & $(50.5)$ \\
\hline $41-50$ & 47 & (7.8) \\
\hline $51-60$ & 19 & (3.2) \\
\hline \multirow{2}{*}{\multicolumn{3}{|c|}{ Mean age $=32.6 \pm 7.8$ years }} \\
\hline & & \\
\hline \multicolumn{3}{|c|}{ Religion } \\
\hline Christianity & 498 & $(83.0)$ \\
\hline Islam & 102 & $(17.0)$ \\
\hline Total & 600 & $(100.0)$ \\
\hline \multicolumn{3}{|l|}{ Tribe } \\
\hline Yoruba & 548 & (91.3) \\
\hline Igbo & 36 & $(6.0)$ \\
\hline Edo & 7 & $(1.2)$ \\
\hline Ijaw & 5 & $(0.8)$ \\
\hline Ibira & 4 & $(0.7)$ \\
\hline Total & 600 & $(100.0)$ \\
\hline \multicolumn{3}{|l|}{ Cadre } \\
\hline Doctor & 127 & $(21.2)$ \\
\hline Nurse & 184 & (30.7) \\
\hline Pharmacist & 92 & (15.3) \\
\hline Com Health & & \\
\hline Workers & 58 & (9.7) \\
\hline Laboratory Staff & 65 & $(10.8)$ \\
\hline Others & 74 & $(12.3)$ \\
\hline Total & 600 & (100.0) \\
\hline
\end{tabular}

Researchers' Survey, 2016 
Table 2: Participants' Knowledge of how EVD can be contacted

\begin{tabular}{lll}
\hline How can Ebola be contacted & Frequency & Percentage (\%) \\
\hline Through blood and bodily fluids of an infected person & 508 & $(84.7)$ \\
Eating of bush meat & 30 & $(5.0)$ \\
No response & 16 & $(2.7)$ \\
Rat to Human & 12 & $(2.0)$ \\
Air borne & 10 & $(1.7)$ \\
Leftover food & 10 & $(1.7)$ \\
Through sex & 8 & $(1.3)$ \\
Through hand shake & 6 & $(1.0)$ \\
Total & $\mathbf{6 0 0}$ & $\mathbf{( 1 0 0 . 0 )}$ \\
\hline
\end{tabular}

Researchers' Survey, 2016

Table 3: Participants' Knowledge of how EVD can be prevented

\begin{tabular}{lll}
\hline Prevention of Ebola & Frequency & Percentage (\%) \\
\hline Avoiding direct contact with an infected person & 468 & $(78.0)$ \\
Practicing Universal Precaution (use of gloves, facial mask etc.) & 172 & $(28.7)$ \\
Avoiding eating of Bush Rats & 128 & $(21.3)$ \\
Avoid contact with animals & 88 & $(14.7)$ \\
Proper Hygiene & 52 & $(8.7)$ \\
Isolation of infected person & 30 & $(5.0)$ \\
Don't know & 36 & $(6.0)$ \\
Surveillance and contact tracing & 14 & $(2.3)$ \\
\hline
\end{tabular}

Researchers' Survey, 2016 Multiple responses

Table 4: Participants' Knowledge of Signs and Symptoms of EVD

\begin{tabular}{lll}
\hline Signs and Symptoms of Ebola & Frequency & Percentage (\%) \\
\hline Bleeding from Orifice & 228 & $(76.0)$ \\
Body pain & 56 & $(18.7)$ \\
Diarrhoea & 72 & $(24.0)$ \\
Fatigue & 26 & $(8.7)$ \\
Fever & 142 & $(47.3)$ \\
Headache & 84 & $(28.0)$ \\
Skin rashes & 21 & $(7.0)$ \\
Red eyes & 15 & $(5.0)$ \\
Sore throat & 34 & $(11.3)$ \\
Stomach pain & 17 & $(5.7)$ \\
Vomiting & 51 & $(17.0)$ \\
Weakness of the body & 42 & $(14.0)$ \\
High body temperature & 91 & $(30.3)$ \\
Malaise & 9 & $(3.0)$ \\
Multiple organ failure & 4 & $(1.3)$ \\
Don't know & 8 & $(2.7)$ \\
\end{tabular}

Researchers'Survey, 2016 Multiple responses

Table 5: Overall Knowledge of EVD by Participants

\begin{tabular}{lll}
\hline Knowledge Score & Frequency & Percentage (\%) \\
\hline Good & 196 & $(32.7 \%)$ \\
Fair & 288 & $(48.0)$ \\
Poor & 116 & $(19.3)$ \\
Total & $\mathbf{6 0 0}$ & $\mathbf{( 1 0 0 . 0 )}$ \\
\hline
\end{tabular}

Point<5: poor; 5-10: fair ;> 10: good. Researchers’ Survey, 2016 